Dzielnicka, E. (2013). Współpraca pracodawców ze szkołami zawodowymi. Teraźniejszość i przyszłość. Warszawa: Krajowy Ośrodek Wspierania Edukacji Zawodowej i Ustawicznej.

Freire, P. (1970). Pedagogy of the Oppressed. N. Y.: Herder and Herder.

Hayden, M.C., Levy, J., \& Thompson, J.J. (2006). Handbook of Research in International Education. London: Sage.

Holland, Y. L. (1968). Explorations of a theory of vocational choice. Journal of Applied Psychology, 52(1), 13-27.

Knowles, M.S. (1984). Andragogy in action: Applying modern principles of adult learning. San Francisco, California: Jossey-Bass.

Knowles, M. S. (1995). Designs for adult learning: practical resources, exercises, and course outlines from the father of adult learning. Alexandria, VA: American Society for Training and Development.

Knowles, M.S., Holton III, E.E., \& Swanson, R.A. (2005). The Adult Learner: The Definitive Classic in Adult Education and Human Resource Development (6th ed.). London, New York, etc.: ELSEVIER Butterworth Heinemann.

Merriam, S.B. (2004). The changing landscape of adult learning theory. In J. Comings, B. Garner, \& C. Smith (Eds.), Review of adult learning and literacy (Vol. 4, pp. 199-220). Mahwah, NJ: Lawrence Erlbaum Associates.

Mezirow, J. (1991). Transformative dimensions of adult learning. San Francisco: Jossey-Bass Inc.

Nottingham Andragogy Group. (1986). Towards Developmental Theory of Andragogy. Nottingham: University of Nottingham.

Баніт, О. (2018). Systemy profesiinoho rozvytku menedzheriv u transnatsionalnykh korporatsiiakh: dosvid Nimechchyny i Polshchi [Systems of professional development of managers in multinational corporations: the experience of Germany and Poland]. Monohrafiia. Kyiv: DKS-Tsentr [in Ukrainian].

УДК 378.7: 371.017

DOI: https://doi.org/10.35387/od.1(17).2020.19-29

Бабушко Світлана Ростиславівна - доктор педагогічних наук, професор, завідувач кафредри туризму Національного університету фрізичного виховання і спорту України

ORCID iD: https://orcid.org/0000-0001-8348-5936

E-mail:babushko64sr@gmail.com

\title{
ОСОБЛИВОСТІ РОЗВИТКУ АКТИВНОГО ГРОМАДЯНСТВА ДОРОСЛИХ У СУЧАСНИХ УМОВАХ
}

Анотація. В оглядовій статті проаналізовано досвід європейських країн з розвитку активного громадянства дорослого населення засобами формальної, неформальної та інформальної освіти. Демократичні прочеси, що відбуваються в Україні, актуалізували питання розвитку активного громадянства. Перед освітою постає завдання сорормувати громадянську ідентичність ї̈ громадян, розвинути здатність і готовність до активної участі у житті суспільства, до 
установлення конструктивних відносин на засадах соціального партнерства. Це завдання реалізується не лише у формальній освіті, але й може бути реалізованим, насамперед, у неформальній та інфоормальній освіті, у тому числі й серед дорослих. Уточнено сутність термінів "активне громадянство» $i$ "відповідальне громадянство» у зарубіжному та вітчизняному науковому дискурсах. Здійснено огляд законодавчих документів в європейських країнах $і$ Євросоюзі в цілому щодо "активного громадянства» й розглянуто їх підходи до розвитку активного громадянства. У Франції та Німеччині акцентується політична участь громадянина. У Великій Британії громадянська активність зосереджується на діяльності громади, через діяльність якої зростатиме й соціальна єдність. У прибалтійських країнах концепт громадянської активності пов'язаний із зменшенням ролі держави на користь приватного підприємництва.

Наведено деякі приклади успішних реалізованих ініціатив з розвитку активного громадянства дорослих в Євросоюзі, зокрема через програми Erasmus Plus з виховання активної громадянської позиції, «Європа для громадян», DEAR. Також проаналізовано стан розвитку активного громадянства дорослих в Україні $і$ продемонстровано технологію успішного розвитку навичок активного громадянства на прикладі «Школи активного громадянина». Як висновок, активне громадянство повинно підтримувати розвиток суспільства і вважатися зобов'язанням навчатися впродовж життя.

Ключові слова: активне громадянство, відповідальне громадянство, освіта дорослих, європейський досвід, Україна, успішні приклади.

Babushko Svitlana - Doctor of Sciences in Pedagogy, Professor, Head of Tourism Department at National University of Ukraine on Physical Education and Sport

ORCID iD: $h$ ttps://orcid.org/0000-0001-8348-5936

E-mail: babushko64sr@gmail.com

\section{PECULIARITIES OF DEVELOPING ADULTS' ACTIVE CITIZENSHIP NOWADAYS}

Abstract. The article analyzes the experience of European countries in the development of active citizenship of the adult population through formal, non-formal and informal education. The democratic processes taking place in Ukraine have made the issue of the development of active citizenship the spotlight. Education is faced with the task of forming the civic identity of its citizens, developing the ability and readiness to actively participate in the life of the society, establishing constructive relations on the basis of social partnership. This task is realized not only within formal education, but also, it can be realized within non-formal and informal education, among adults, as well. 
The essence of the terms "active citizenship» and "responsible citizenship» in foreign and domestic scientific discourses is specified. Legislative documents on "active citizenship» in European countries and the European Union as a whole entity were reviewed and their approaches to the development of active citizenship were considered. In France and Germany, the political aspect of active citizenship is emphasized. In the UK, civic activism focuses on community activities, which will increase social cohesion, that is social aspect is underlined. In the Baltic countries, the concept of civic activism is associated with reducing the role of the state for the sake of entrepreneurship. In other words, economic aspect of active citizenship is stressed. Some examples of successful initiatives of developing active adult citizenship in the European Union were described, in particular through the Erasmus Plus programs for active citizenship, "Europe for Citizens», "DEAR». The state of developing active adult citizenship in Ukraine was also analyze" and the successfully realized initiative of developing active citizenship skills was demonstrated on the example of the "Active Citizen's School».

In conclusion, active citizenship should support the development of the society and be considered a lifelong learning obligation.

Key words: active citizenship, responsible citizenship, adult education, European experience, Ukraine, successful examples.

Постановка проблеми, ї̈ актуальність. Участь України в загальносвітових політичних, економічних і соціокультурних процесах, i водночас прагнення українців до збереження національних ідеалів та самобутності зумовили появу нових соціально-політичних реалій суспільства. Їх основою є демократичні процеси, свобода, повага до прав людини, солідарність і участь в житті суспільства. Наявність у країні громадян, які активно цікавляться суспільним, політичним та економічним життям, вже стала показником успішності розвитку демократичного суспільства. Тому активне громадянство сприймається нині як норма, а перед освітою постає вагоме завдання - сфрормувати громадянську ідентичність, здатність і готовність до активної участі у житті суспільства, до установлення конструктивних відносин на засадах соціального партнерства. Прикметно, що це завдання може бути виконаним не лише у формальній освіті, але й, насамперед, у неформальній та інфрормальній. У цьому випадку, акцент у реалізації поставлених завдань зміщується з розвитку загальногромадських цінностей суспільства на заохочення до активної участі у житті своєї громади (Burls and Recknagel, 2013). Процеси децентралізації в Україні й реформування місцевого самоврядування, формування об'єднаних територіальних громад свідчать, що громадяни почали проявляти громадянську активність, цікавитися та брати участь у процесах прийняття важливих рішень у громаді. Іншими словами, вони активно впливають на якість свого життя, і зрештою, всієї країни. Таким чином, питання розвитку активного громадянства актуалізувалося, що й зумовило вибір теми дослідження. 
Аналіз останніх досліджень і публікацій. Огляд літератури 3 досліджуваної теми свідчить, що питання виховання відповідального громадянина постійно перебуває в колі інтересів науковців з часів Платона і Цицерона. Чимало уваги було приділено питанням громадянського виховання і у працях таких відомих педагогів як Я. Коменського, Дж. Лока, Й. Песталоцці. Лейтмотивом праць К. Ушинського проходить думка, що в моральній основі громадянина лежить почуття національної самосвідомості, любові до Батьківщини. Поняття «громадянськість» було одним з ключових у педагогічній спадщині В. Сухомлинського.

Публікації сучасних вітчизняних науковців-педагогів стосуються, насамперед, формування громадянської відповідальності, виховання свідомого громадянина такої категорії осіб, як учні шкіл (Богомолова, 2014; Івашковський, 2010). Це й недивно, адже школа - це найважливіше місце та середовище для формування громадянських компетенцій молодої людини та її підготовки до активного життя в соціумі. Так, Н. Богомолова (2014) розглядає процес формування громадянина України в системі загальноосвітніх навчальних закладів. Дослідниця зазначає, що в сучасній школі для становлення громадянина використовується переважно когнітивний підхід, тобто учні отримують певний багаж знань громадянознавчого змісту. При цьому, отримані знання не перетворюється на духовні орієнтації особистості, а залишаються лише на рівні інформації (Богомолова, 2014, с. 78). Відтак, дослідниця наголошує на необхідності більшого використання потенціалу позакласної діяльності як найбільш дієвого процесу формування громадянськості. Суголосним до викладеного вище $є$ й позиція А. Супруненко (2013), яка розкриває у своїх працях можливі шляхи розвитку в учнів високих показників громадянської відповідальності та патріотизму не лише завдяки загальноосвітнім предметам, що вивчаються у школі, але, передусім, завдяки позакласній роботі. Іншими словами, неформальна та інформальна освіта мають величезний потенціал для формування в учнів активної громадянської позиції. Важливим $€$ також питання громадянського виховання молодого покоління у сім'ї, завдяки ії цінностям, традиціям, прикладу старших поколінь (Федаєва, 2006), тобто засобами інформальної освіти.

Щодо формування активної громадянської позиції інших категорій населення питання частково розглядається 3 позицій соціальної відповідальності (Охріменко, Іванова, 2015) чи політичної освіти (Тимків, 2015). Однак, питання формування активного громадянства дорослого населення поки що залишалося поза увагою українських науковців. Хоча, як справедливо наголошував С. Гончаренко (1997, с.75), основні риси громадянина закладаються в дитячому, підлітковому, юнацькому віці на основі досвіду, набутого в родині, школі, соціальному середовищі, однак формуються в подальшому протягом усього життя людини.

Натомість, у зарубіжному науковому просторі це питання останнім часом набуло актуальності й привернуло увагу значної кількості науковців. Крім того, це питання висвітлено і в офіційних документах європейських країн і Євросоюзу, що буде розкрито далі. 
Мета статті. Зважаючи на достатній досвід європейських країн 3 розвитку активного громадянства дорослого населення засобами формальної, неформальної та інформальної освіти, у своїх пошуках звернемося до аналізу й виокремлення його позитивних ідей. Для досягнення поставленої мети здійснимо аналіз концепту «активне громадянство» у зарубіжному та вітчизняному науковому дискурсах; огляд підходів до розвитку активного громадянства в європейських країнах $\mathrm{i}$ Євросоюзі в цілому; вивчення вітчизняного досвіду розвитку активного громадянства.

Виклад основного матеріалу дослідження. Часто терміни «активне громадянство» та «відповідальне громадянство» вживаються як синоніми. Так, в урядових політичних документах Угорщини повсякчасно вживається саме другий термін. Разом з тим, у Стратегії уряду Угорщини 3 навчання упродовж життя на 2007-2013 рр. вживався й термін «активне громадянство». Його показниками визначено участь у виборах, показники довіри до державних установ, показники корупції, показники освіти та добробуту (середня оцінка телевізійних програм, рівень розлучень, частота випадків смерті, пов'язаних з алкоголізмом, низький рівень народжуваності) (Government, 2005, с. 25). У документі йдеться про те, що стратегія навчання протягом усього життя може бути продуктивно реалізована лише за умови наявності у людей позитивного соціального бачення майбутнього на основі суспільного консенсусу. Це дає підстави для наступного умовиводу: активне громадянство нерозривно пов'язане з державними установами і представницькою демократією в традиційному розумінні, а від громадян не очікується жодних ініціатив.

Як зазначається у звіті Broad Research (2017, с. 14), у посткомуністичних країнах вживали переважно термін «відповідальне громадянство», оскільки він відображав нерозривний зв'язок 3 громадськими організаціями та представницькою демократією у традиційному смислі. Іншими словами, від громадян не передбачалося жодних ініціатив. Натомість, у зарубіжному науковому дискурсі «активне громадянство» розглядають, насамперед, як ініціативу, що проявляється у соціальному, політичному та економічному вимірах (Broad Research, 2017, c. 505).

Аналіз вітчизняних джерел з цього питання дійсно свідчить про використання терміну «відповідальне громадянство», «відповідальний громадянин». Попри це, вивчення механізмів фоомування відповідального громадянина демонструє й очікування від громадянина активної життєвої позиції, його участі у громадському житті, внесенні ініціатив та їх реалізації. Тобто, незважаючи на відмінність у термінології, сутність обох термінів можна вважати ідентичною. Таким чином відбулося розширення змістового наповнення терміну.

Загалом, активне громадянство розглядають у 3-х вимірах:

соціальному, який спрямовано на розвиток соціальних компетентностей, соціального капіталу;

політичному, який сприяє громадянській та політичній 
активності, участі у діяльності місцевих громад, усвідомленні своїх прав; економічному, який стосується зайнятості, зокрема розвиток навичок зайнятості, доступ до соціальних пільг (Broad Research, 2017, c. 505).

Вивчення досвіду європейських країн дає підстави стверджувати, що концепція активного громадянства широко використовується, однак у кожній країні все ж таки з дещо різним баченням. Іншими словами, значення терміну «активне громадянство» залежить від акцентів і пріоритетів, які висуваються країною до досліджуваного феномену. Наприклад, у Франції та Німеччині акцентується політична участь громадянина. Важливо, щоб громадяни брали активну участь у політичному житті країни, тобто підкреслюється політичний аспект активного громадянства. Натомість, у Великій Британії громадянська активність зосереджується на діяльності громади, через діяльність якої зростатиме й соціальна єдність, тобто акцентується соціальний аспект активного громадянства.

У прибалтійських країнах простежуються інші тенденції - на перший план виходить економічна складова активного громадянства. Так, в Естонії спостерігається позитивний вплив громадян на суспільство завдяки їх прагненню i водночас наявності у них розвинених демократичних компетентностей. У навчальних програмах рівня середньої та старшої шкіл концепцію активного громадянства відображено у громадянській ініціативі та підприємництві, мета якої - сприяти, щоб молоді люди стали активними та відповідальними членами суспільства.

У Латвії концепцію «активних і відповідальних громадян» відображено у політичному документі «Стратегія сталого розвитку Латвії до 2030 року» (Sustainable Development). Зокрема, зазначається, що кожен громадянин повинен мати можливість відчувати себе безпечно і мати відчуття належності до Латвії, кожен буде мати можливість досягти поставлених цілей.

У Литві концепцію активного громадянства викладено опосередковано у програмі «Стратегія розвитку Литви до 2030». Громадяни описуються як активні, заповзятливі, творчі в своїх рішеннях, готові до ризику та як такі, що довіряють своїм співгромадянам. Громадяни мають брати відповідальність не тільки за себе, але й за інших членів суспільства, їм має бути притаманне почуття національної свідомості та самосвідомості. Образ громадянина як активної та відповідальної особи, що демонструє «зростаючу громадянську зрілість», пов'язаний 3 ідеологією, яка націлена на те, що уряд має зменшити своє втручання, таким чином даючи можливість громадянам і громадам взяти на себе відповідальність (Lietuva, 2020). Відтак, концепт громадянської активності у Литві пов'язаний із зменшенням ролі держави на користь приватного підприємництва.

Варто зауважити, що незважаючи на деякі відмінності у реалізації концепту активного громадянства у європейських країнах, всі вони розроблені в контексті Комюніке Європейської комісії від 2001 р. 
«Перетворення Європейського простору освіти упродовж життя на реальність». У цьому документі «активне громадянство» визначається як одна із 4-х взаємопов'язаних цілей стратегії освіти упродовж життя (European Commission, 2001). Вже у 2006 р. Європарламентом і Радою Євросоюзу було наголошено, що активне демократичне громадянство, як ключова компетентність для освіти упродовж життя, озброює особу необхідним для повноцінної участі у громадянському житті й базується на знаннях соціально-політичних концептів і структур та прагнення активно брати в демократичних процесах у суспільстві.

Європейська програма освіти дорослих (2010) називає активне громадянство однією з основних причин, чому участь дорослих у формальній, неформальній та інформальній освіті невпинно зростає, одночасно із набуттям трудових навичок та особистісним розвитком.

Приклади успішних реалізованих ініціатив з розвитку активного громадянства дорослих в Євросоюзі - це програми Erasmus Plus 3 виховання активної громадянської позиції, а також програма «Європа для громадян», що має на меті сприяти зростанню розуміння громадянами ЄС його історії та різноманітності, покращення умов для громадян i демократична участь на рівні ЄС. Програми «Європа для громадян» включає дві складові:

- «Європейську пам'ять», програму, що підтримує проекти, мета яких з'ясувати причини виникнення тоталітарних режимів у сучасній Європі, та проекти, що стосуються інших визначальних моментів у новітній європейській історії

- «Демократичну участь і громадянськість», програму, що підтримує проекти, які дозволяють громадянам брати участь у демократичному житті $€$, починаючи від місцевої демократії до надання громадянам можливості брати повноцінну участь у політиці $€ С$.

Крім того, громадянська освіта для дорослих, а відтак і розвиток активного громадянства, просувається через програму DEAR, націлену на розвиток громадянської освіти в глобальному контексті. Основні цілі програми включають «інформування громадян $Є С$ щодо питань розвитку, сприяння усвідомленню та розумінню глобального розвитку і визнання взаємозалежності», а також «забезпечення європейської громадськості інструментами критичної взаємодії з глобальним розвитком і всебічна підтримка появи нових ідей з питань розвитку».

На відміну від перших двох згаданих програм «Erasmus Plus» та «Європа для громадян» програма DEAR також підтримує ідеї розвитку активного громадянства, однак реалізується партнерами поза межами Європейського Союзу.

Феномен активного громадянства поступово отримує визнання й в Україні, розпочавши свій шлях з розвитку громадянської освіти. 3 метою реалізації державної політики, спрямованої на формування сприятливого середовища для становлення в Україні громадянського суспільства, досягнення європейських стандартів забезпечення та захисту прав i свобод людини і громадянина, розроблено проект Концепції громадянської 
освіти та виховання в Україні (2012). У Концепції зазначається, що провідну роль у реалізації громадянської освіти відіграють навчальні заклади та сімейне виховання, політичні партії, громадські організації та засоби масової інфоормації.

Інститут лідерства та управління, виходячи з набутого 4-річного досвіду у зазначеній царині, підкреслює соціальний аспект активного громадянства. Експерти Інституту вказують, що низка визначень «активного громадянства» має право на існування, адже кожне з них може бути актуальним для різних національних контекстів (Інститут, 2019). Разом 3 тим, принципи активного громадянства - універсальні, адже всі люди мають право голосу і несуть відповідальність у своїх громадах. Вони також наділені лідерськими здібностями та мають право впливати на встановлення правил життя у суспільстві. Рисами активного громадянина, насамперед, є піклування про спільноту і соціальну єдність, спілкування 3 іншими, а також вирішення проблем і розвиток суспільства.

Вітчизняним прикладом успішного розвитку навичок активного громадянства у молоді після закінчення школи є започаткування так званої «Школи активного громадянина». Ця програма $\epsilon$ частиною Проекту «Відповідальна молодь проти корупції», що реалізується Донецьким молодіжним центром за підтримки Програми сприяння громадській активності «Долучайся!», фрінансується Агентством США з міжнародного розвитку (USAID) та впроваджується Pасt в Україні. Метою школи $є$ підвищення рівня обізнаності молоді з питань активізації молоді, посилення їх громадянської позиції, залучення до громадського та політичного життя громади та країни, набуття навичок адвокації, критичного мислення та публічного виступу. Поставлені цілі досягаються шляхом проведення п'ятиденного навчання у Школі активного громадянина. Типові методи навчання в цій школі $\epsilon$ інноваційними й охоплюють інтерактивне спілкування, роботу в групах, дебати, рольові ігри, вокршопи. Першими 50 учасниками програми стали представники з Донецької, Луганської, Запорізької, Дніпропетрівської та Харківської областей. Вікові обмеження 18-25 років (Школа, 2020).

Висновки i перспективи подальших досліджень. Проаналізований досвід європейських країн свідчить, що розвиток активного громадянства дорослих відбувається безпосередньо чи опосередковано через низку освітніх програм для дорослих, які спрямовано на розвиток соціальних, політичних та економічних навичок, у різних видах освіти дорослих та навчання протягом усього життя (наприклад, професійній освіті, освіті другого шансу, перенавчанні тощо). Тобто не лише формальна, але й неформальна та інформальна освіта сприяють розвитку активного громадянства дорослих.

Таким чином, викладене вище дає підстави для висновку, що активне громадянство не повинно зводитися лише до громадянської освіти, не повинно обмежуватися частиною шкільної програми і навіть формальною освітою загалом, а повинно підтримувати розвиток суспільства і вважатися зобов'язанням навчатися впродовж життя. 


\section{Список використаних джерел}

Богомолова, Н. М. (2014). Формування громадянина в системі загальноосвітніх навчальних закладів в умовах розвитку громадянського суспільства в Україні. Наукові записки НДУ ім. М. Гоголя. Психолого-педагогічні науки. 4, 76-80.

Гончаренко, С. (1997). Український педагогічний словник. Київ: Либідь.

Івашковський, В. В. (2010). Теоретико-методичні засади виховання старшокласників як суб'єктів громадянського суспільства: монографія. К.: Паливода А. В.

Інститут лідерства та управління. (2019). Активне громадянство в Україні: над чим ще працювати? http://management.lviv.ua/aktualno/news/item/

Концепція громадянської освіти та виховання в Україні (проект). (2012). URL: http://www.mon.gov.ua/ua/pr-viddil/1312/2012_rik/

Охріменко, О. О., Іванова, Т. В. (2015). Соціальна відповідальність. К.: Національний технічний університет України «КПІ».

Супруненко, А. Г. (2013). Громадянське виховання школярів на уроках історії в загальноосвітній школі. Педагогіка формування творчої особистості у вищій і загальноосвітній школах. 30 (83), 502-508.

Тимків, І. (2019). Особливості формування громадянина сучасної України у контексті політичного виховання. Науковий вісник Харківського національного педагогічного університету ім. Г. Сковороди. Серія Філософія. 45(II), 151-160. URL: http://doi.org/10.5281/zenodo.32479

Федаєва, В. (2006). Сім'я як носій громадянського виховання. Вісник Львів. унту. Серія: Педагогіка. 21(1), 146-152.

Школа активного громадянина. (2020). Громадський простір. https://www. prostir.ua/?grants=nabir-uchasnykiv-na-shkolu-aktyvnoho-hromadyanyna

Broad Research on Adult Education in the EU. (June, 2017). Deliverable 2.1. ed. by N. Kersh, H. Toiviainen. 512 p. URL: http://www.uta.fi/edu/en/transit/ index/D2.1.Report.30.6.2017.pdf

European Commission (2001). Making a European area of lifelong learning a reality. 678 final. URL: https://eur-lex.europa.eu/LexUriServ/LexUriServ.do?uri= COM:2001:0678:FIN:EN:PDF

Government (2005). Strategy of the Government of the Republic of Hungary for Lifelong Learning. September $2005 . \quad$ URL: https://uil.unesco.org/document/hungary-strategy-government-republichungary-lifelong-learning-issued-2005

Lietuva 2030. (2020). Lithuania's Progress Strategy. https://lrv.It/uploads/main/documents/files/EN_version/Useful_information/li thuania2030.pdf

Recommendation of the European Parliament and of the Council of 18 December 2006 on key competences for lifelong learning. (2006). Official Journal of the European Union. URL: https://eurlex.europa.eu/LexUriServ/LexUriServ. do?uri=OJ:L:2006:394:0010:0018:en:PDF

Sustainable Development Strategy of Latvia until 2030. SAEIMA of the Republic of Latvia. (2020). https://www.pkc.gov.Iv/sites/default/files/inlinefiles/LIAS_2030_en_1.pdf

The European Agenda for Adult Learning. (2010). URL: https://eur-lex. europa.eu/legalcontent/EN/TXT/HTML/?uri=CELEX:32011G1220 (01)\&from=EN 


\section{References (translated and transliterated)}

Boghomolova, N. M. (2014). Formuvannja ghromadjanyna v systemi zaghaljnoosvitnikh navchaljnykh zakladiv $v$ umovakh rozvytku ghromadjansjkogho suspiljstva $v$ Ukrajini. [Formation of a citizen at comprehensive educational establishments in Ukraine]. Naukovi zapysky NDU im. M. Ghogholja. Psykhologho-pedaghoghichni nauky. - Scientific Bulletin of M. Gogol National University. Psychological and Pedagogical Sciences. 4, 76-80 [in Ukraine]

Ghoncharenko, S. (1997). Ukrajinsjkyj pedaghoghichnyj slovnyk [Ukrainian pedagogical dictionary]. Kyjiv: Lybidj [in Ukraine]

Ivashkovsjkyj, V. V. (2010). Teoretyko-metodychni zasady vykhovannja starshoklasnykiv jak sub'jektiv ghromadjansjkogho suspiljstva [Theoretical and methodical grounds of high school students' education as subjects of civil society]: monoghrafija. K.: Palyvoda A. V. [in Ukraine]

Instytut liderstva ta upravlinnja. (2019). Aktyvne ghromadjanstvo v Ukrajini: nad chym shhe pracjuvaty? [Active citizenship in Ukraine: what else should be worked at?]. http://management.Iviv.ua/aktualno/news/item/ [in Ukraine]

Koncepcija ghromadjansjkoji osvity ta vykhovannja v Ukrajini (proekt). [Concept of civil education in Ukraine. (project)]. (2012). URL: http://www.mon.gov.ua/ua/pr-viddil/1312/2012_rik/ [in Ukraine]

Okhrimenko, O. O., Ivanova, T. V. (2015). Socialjna vidpovidaljnistj. [Social responsibility]. K.: Nacionaljnyj tekhnichnyj universytet Ukrajiny «KPI». [in Ukraine]

Suprunenko, A. Gh. (2013). Ghromadjansjke vykhovannja shkoljariv na urokakh istoriji v zaghaljnoosvitnij shkoli. [Civil education of schoolchildren in history lessons at secondary school]. Pedaghoghika formuvannja tvorchoji osobystosti u vyshhij i zaghaljnoosvitnij shkolakh. - Pedagogics of forming creative personality at hogher and secondary schools. 30 (83), 502-508 [in Ukraine]

Tymkiv, I. (2019). Osoblyvosti formuvannja ghromadjanyna suchasnoji Ukrajiny u konteksti politychnogho vykhovannja. [Peculiarities of forming a citizen of modern Ukraine through political education]. Naukovyj visnyk Kharkivsjkogho nacionaljnogho pedaghoghichnogho universytetu im. Gh. Skovorody. Serija Filosofija. - Scientific Bulletin of G. Skovoroda Kharkiv national pedagogical university. Seria Philosophy. 45(II), 151-160. URL: http://doi.org/10.5281/zenodo.32479 [in Ukraine]

Fedajeva, V. (2006). Sim'ja jak nosij ghromadjansjkogho vykhovannja. [Family as a tool of civil education]. Visnyk Ljviv. un-tu. Serija: Pedaghoghika. - Lviv University Bulletin. Seria Pedagogics. 21(1), 146-152 [in Ukraine]

Shkola aktyvnogho ghromadjanyna. (2020). Ghromadsjkyj prostir. [Public space]. https://www.prostir.ua/?grants=nabir-uchasnykiv-na-shkolu-aktyvnohohromadyanyna [in Ukraine]

Broad Research on Adult Education in the EU. (June, 2017). Deliverable 2.1. ed. by N. Kersh, H. Toiviainen. 512 p. http://www.uta.fi/edu/en/transit/ index/D2.1.Report.30.6.2017.pdf [in English]

European Commission (2001). Making a European area of lifelong learning a reality. 678 final. https://eur-lex.europa.eu/LexUriServ/LexUriServ.do?uri= COM:2001:0678:FIN:EN:PDF [in English]

Government (2005). Strategy of the Government of the Republic of Hungary for 
Lifelong Learning. September $2005 . \quad$ URL: https://uil.unesco.org/document/hungary-strategy-government-republichungary-lifelong-learning-issued-2005 [in English]

Lietuva 2030. (2020). Lithuania's Progress Strategy. URL: https://Irv.It/uploads/main/documents/files/EN_version/Useful_information/li thuania2030.pdf [in English]

Recommendation of the European Parliament and of the Council of 18 December 2006 on key competences for lifelong learning. (2006). Official Journal of the European Union. URL: https://eurlex.europa.eu/LexUriServ/LexUriServ. do?uri=OJ:L:2006:394:0010:0018:en:PDF [in English]

Sustainable Development Strategy of Latvia until 2030. SAEIMA of the Republic of Latvia. (2020). URL: https://www.pkc.gov.Iv/sites/default/files/inlinefiles/LIAS_2030_en_1.pdf [in English]

The European Agenda for Adult Learning. (2010). URL: https://eur-lex. europa.eu/legalcontent/EN/TXT/HTML/?uri=CELEX:32011G1220 (01)\&from=EN [in English]

УДК 37.018.43:[044+621.397.122]

DOI: https://doi.org/10.35387/od.1(17).2020.29-39

Головченко Гліб Олександрович - кандидат педагогічних наук, дочент, директор Коледжу преси та телебачення, м. Миколаїв

ORCID iD: http://orcid.org/0000-0003-1734-6430

E-mail:g.golovchenko@gmail.com

\section{АНАЛІЗ ДІЯЛЬНОСТІ ЦЕНТРІВ МЕДІАОСВІТИ В УКРАÏНІ}

Анотація. Автором оглядової статті наголошено, що епоха цифрового суспільства вимагає від нинішніх громадян вільного володіння новими навичками для успішного використання можливостей новітньої реальності - медіаінформаційними. Відтак, все більшої вагомості набуває медіаосвіта. ЮНЕСКО навіть визнає медіа освіту окремою складовою освіти. Україна вже має певний позитивні здобутки з ії провадження у формальній, нефоормальній та інфоормальній освіті. У публікації здійснено спробу систематизувати набутий досвід через призму діяльності вітчизняних медіаосвітніх центрів.

Для досягнення поставленої мети було використано комплекс теоретичних методів дослідження для вивчення напрямів провадження вітчизняної медіаосвіти: огляд літератури, відбір $i$ й осмислення результатів, їх систематизація та визначення перспектив. Описано діяльність 3 визнаних вітчизняних иентрів медіаосвіти: Інституту соціальної та політичної психології, Інституту вищої освіти Національної академії педагогічних наук України та Інституту екології масової інфрормації. Узагальнення та систематизація їх медіаосвітньої діяльності уможливили виокремлення наступних критеріїв: історичного, методичного, прогностичного.

Завдяки їх використанню, було визначено й 2 нових медіаосвітніх 